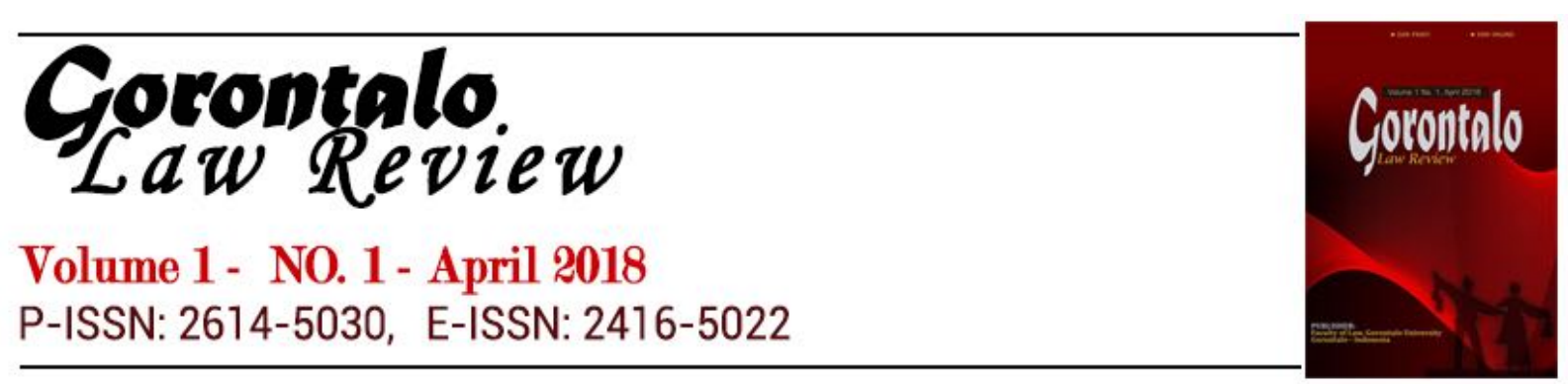

\title{
Tinjauan Yuridis tentang Rechtvinding (Pemenuhan Hukum) dalam Hukum Perdata Indonesia
}

\author{
Nurmin K Martam \\ Ilmu Hukum Fakultas Hukum Universitas Gorontalo \\ email : nmartam@yahoo.com
}

\begin{abstract}
Research Title "Juridical Review About Rechtvinding (Legal Discovery) in Indonesian Civil Law". Faculty of Law, University of Gorontalo.

The law has a function to provide protection to human interests (all human beings without exception). Therefore, the law must be implemented so that human interest can be protected. In practice, the law may proceed normally and peacefully, but there may also be legal violations in practice. In this case the law that has been violated must be enforced. It is through law enforcement that this law becomes a reality. In upholding the law there are three elements that must always be considered: legal certainty (Rechtssicherheit), usefulness (Zweckmassigkeit) and justice (Gerechtigkeit).

In the life of society required a legal system to create a harmonious and orderly society life. In fact the law or legislation that is made does not cover all cases that arise in society, making it difficult for law enforcement to complete the case. In the scope of positive law in Indonesia, the principle "that judges should not refuse a case", contained in article 10 paragraph (1) of Law no. 44 Year 2009 on Judicial Power.

Constitutional judges and judges are required to explore, follow, and understand the legal values and sense of justice living in society. This is the basis that it is unavoidable that the rechtsvinding process should still be done by the judge in deciding cases not found clearly and firmly in legislation.

The approach used in this study is a normative juridical approach, namely by using the theories and opinions of scholars by conducting an analysis of the provisions applicable in positive law of Indonesia.

In line with the increasingly dynamic society, it demands a dynamic legal development as well. This is in line with the civil law system itself that is dynamic and not static. The important task of the judge, therefore, is to adapt the law to concrete events in society. If the law can not be judged appropriately according to the words of the law or the law is unclear, then the judge must interpret the law, so that the judge can make a truly fair law decision in accordance with what Which is the purpose and objective of the law, namely the achievement of legal certainty.
\end{abstract}

Keywords: Legal Discovery, Rechtsvinding

\section{PENDAhUluan}

Hukum mempunyai fungsi untuk memberikan perlindungan terhadap kepentingan manusia (seluruh manusia tanpa terkecuali). Oleh karena itu maka hukum harus dilaksanakan agar kepentingan manusia tersebut dapat terlindungi. Dalam pelaksanaannya, hukum dapat berlangsung secara normal dan damai, akan tetapi dapat juga terjadi pelanggaran-pelanggaran hukum dalam prakteknya. Dalam hal ini hukum yang telah dilanggar itu harus 
ditegakkan. Melalui penegakan hukum inilah hukum ini menjadi kenyataan. Dalam menegakkan hukum ada tiga unsur yang selalu harus diperhatikan : kepastian hukum (Rechtssicherheit), kemanfaatan (Zweckmassigkeit) dan keadilan (Gerechtigkeit). Hukum harus dilaksanakan dan ditegakkan. Setiap orang mengharapkan dapat ditetapkannya hukum dalam hal terjadi peristiwa konkrit. Bagaimana hukumnya itulah yang harus berlaku "fiat justitia et pereat mundus" (meskipun dunia ini runtuh hukum harus ditegakkan).Dalam lingkup hukum positif di Indonesia, asas "bahwa hakim tidak boleh menolak suatu perkara", yang termuat dalam pasal 10 ayat (1) Undang-undang No. 44 Tahun 2009 tentang Kekuasaan Kehakiman, yang menyatakan bahwa:

Pengadilan dilarang menolak untuk memeriksa, mengadili, dan memutus suatu perkara yangdiajukan dengan dalih bahwa hukum tidak ada atau kurang jelas, melainkan wajib untukmemeriksa dan mengadilinya. ${ }^{1}$

Dan dijelaskan pula dalam Pasal 5 Undang-undang No. 44 Tahun 2009 tentang Kekuasaan Kehakiman, yang menyatakan bahwa:

Hakim dan hakim konstitusi wajib menggali, mengikuti, dan memahami nilai-nilai hukum danrasa keadilan yang hidup dalam masyarakat. ${ }^{2}$

Hal inilah menjadi dasar bahwa merupakan sesuatu yang tidak dapat dihindarkan bahwa proses rechtsvinding harus tetap dilakukan oleh hakim dalam memutuskan perkara yang tidak ditemukan secara jelas dan tegas dalam peraturan perundang-undangan.

Oleh karena itu ijtihad harus dilakukan, karena meniadakan ijtihad dapat melahirkan kevakuman hukum. ${ }^{3}$

Pada dasarnya hukum itu merupakan sarana untuk mengatur kehidupan sosial, namun satu hal yang menarik adalah bahwa justru ia hampir senantiasa tertinggal di belakang obyek yang diaturnya. Dan ketinggalan ini akan betulbetul menimbulkan suatu persoalan pada saat jarak yang memisahkan antara peraturan formal dengan kenyataan yang terjadi telah melampaui batasbatasnya yang wajar. ${ }^{4}$

Dari keterangan di atas dapat diketahui, bahwa tertinggalnya hukum di belakang masalah yang diaturnya merupakan persoalan, pada saat jarak ketinggalan itu telah sedemikian menyoloknya, sedangkan penyesuaian yang semestinya dapat mengurangi ketegangannya belum kunjung berhasil seperti yang diharapkan. 5

\section{KAJIAN TEORI}

A. Rechtvinding (Penemuan Hukum)

Rechtsvinding, berasal dari bahasa Belanda yang terdiri dari kata "recht" yang berarti "hukum", dan "vinding" yang berarti "penemuan". 6 Jadi, kata rechtsvinding dapat diartikan sebagai "penemuan hukum". Sering dipermasalahkan mengenai istilah "penemuan hukum"; apakah tidak lebih tepat

\footnotetext{
${ }^{1}$ Lihat Pasal 10 ayat 1 Undang-Undang No. 44 Tahun 2009 tentang Kekuasaan Kehakiman.

${ }^{2}$ Lihat Pasal 5 Undang-Undang No. 44 Tahun 2009 tentang Kekuasaan Kehakiman

${ }^{3}$ Asafri Jaya Bakri, KonsepMaqashid Syari'ah Menurut Al-Syatibi, Jakarta, Rajawali Press, 1996, hlm 168.

${ }^{4}$ Satjipto Rahardjo, Hukum Dan Masyarakat, Bandung, Angkasa, 1986, hlm 99.

${ }^{5}$ Ibid, hlm 100.

${ }^{6}$ Datje Raharjoekoesoemah, Kamus Bahasa Belanda-Indonesia, Jakarta, Rineka Cipta, 1991, hlm 263 \& 720.
} 
istilah pelaksanaan hukum, penerapan hukum, pembentukan hukum atau penciptaan hukum. ${ }^{7}$

Untuk menjawab permasalahan diatas, kiranya sangatlah penting untuk diketahui terlebih dahulu tentang pengertian dari masing-masing istilah tersebut. Sehingga nantinya dapat diketahui, mana istilah yang dianggap lebih tepat dan mengena.

Pelaksanaan hukum dapat berarti menjalankan hukum tanpa adanya sengketa atau pelanggaran. Ini meliputi pelaksanaan hukum oleh setiap warga negara setiap hari yang sering tidak disadarinya dan juga oleh aparat negara (law enforcement). Disamping itu pelaksanaan hukum dapat terjadi kalau ada sengketa, yaitu yang dilaksanakan oleh hakim. Ini sekaligus merupakan penegakan hukum. ${ }^{8}$

Penerapan hukum tidak lain berarti menerapkan (peraturan) hukum yang abstrak sifatnya pada peristiwanya. Menerapkan (peraturan) hukum pada peristiwa konkrit secara langsung tidak mungkin. Peristiwa konkrit tersebut harus dijadikan peristiwa hukum terlebih dahulu agar peraturan hukumnya dapat diterapkan. Di waktu yang lampau dikatakan bahwa hakim adalah corong undang-undang, karena kewajibannya hanyalah menerapkan undang-undang. ${ }^{9}$

Pembentukan hukum adalah merumuskan peraturan-peraturan umum yang berlaku umum, bagi setiap orang. Kalau lazimnya pembentukan hukum dilakukan oleh pembentuk undang-undang, maka hakim dimungkinkan pula membentuk hukum, kalau hasil penemuan hukumnya itu adalah kemudian merupakan yurisprudensi tetap yang diikuti oleh para hakim dan merupakan pedoman bagi masyarakat, yaitu putusan yang mengandung asas-asas hukum yang dirumuskan dalam peristiwa konkrit, tetapi memperoleh kekuatan berlaku umum. Jadi satu putusan dapat sekaligus mengandung dua unsur, yaitu di satu pihak putusan merupakan penyelesaian atau pemecahan suatu peristiwa konkrit dan di pihak lain merupakan peraturan hukum untuk waktu mendatang. 10

Sedangkan penggunaan istilah penciptaan hukum kiranya dinilai kurang tepat, karena memberi kesan bahwa hukumnya sama sekali tidak ada, kemudian diciptakan, dari tidak ada menjadi ada. Hukum bukanlah selalu berupa kaedah baik tertulis maupun tidak tertulis, tetapi dapat juga berupa perilaku atau peristiwa. Di dalam perilaku itulah terdapat hukumnya. Dari perilaku itulah harus diketemukan atau digali kaedah atau hukumnya. Maka kiranya istilah penemuan hukumlah yang tepat. ${ }^{11}$

Apa yang dimaksud dengan penemuan hukum lazimnya adalah proses pembentukan hukum oleh hakim, atau aparat hukum lainnya yang ditugaskan untuk penerapan peraturan hukum umum pada peristiwa hukum konkrit. Lebih lanjut dapat dikatakan bahwa penemuan hukum adalah proses konkritisasi atau individualisasi peraturan hukum (das Sollen) yang bersifat umum dengan mengingat akan peristiwa konkrit (das Sein) tertentu. ${ }^{12}$

\footnotetext{
${ }^{7}$ Sudikno Mertokusumo, Penemuan Hukum, Yogyakarta, Liberty, 2001, hlm 36.

${ }^{8}$ Ibid.

${ }^{9}$ Ibid.

${ }^{10}$ Ibid.

${ }^{11}$ Ibid, hlm 37

${ }^{12}$ Sudikno Mertokusumo, Bab-Bab Tentang Penemuan Hukum, Yogyakarta, Liberty, 2000, hlm 4.
} 
B. Aliran Rechtsvinding (Penemuan Hukum).

Perubahan pandangan terhadap hukum dewasa ini mulai bergeser sejalan dengan perkembangannya, hal ini dikarenakan:

a. Hukum itu harus berdasarkan asas keadilan masyarakat yang terus berkembang.

b. Ternyata pembuat undang-undang tidak dapat mengikuti kecepatan gerak masyarakat atau proses perkembangan sosial, sehingga penyusunan undangundang selalu ketinggalan.

c. Undang-undang tidak dapat menyelesaikan tiap masalah yang timbul. Undang-undang tidak dapat terinci (mendetail) melainkan hanya memberikan algemeene richtlijnen (pedoman umum) saja.

d. Undang-undang tidak dapat sempurna, terkadang dipergunakan istilahistilah yang kabur dan hakim harus memberikan makna yang lebih jauh dengan cara memberikan penafsiran.

e. Undang-undang tidak dapat lengkap dan tidak dapat mencakup segalagalanya. Di sana sini selalu ada leemten (kekosongan dalam undang-undang), maka hakim harus menyusunnya dengan jalan mengadakan konstruksi hukum melalui, analogi, rechtsverfijningdan argumentum a contrario.

f. Apa yang patut dan masuk akal dalam kasus-kasus tertentu juga berlaku bagi kasus lan yang sama. ${ }^{13}$

Perubahan pandangan terhadap hukum inilah yang menyebabkan timbulnya aliran Rechtsvinding. Menurut aliran Rechtsvinding, ada beberapa cara yang menyebabkan hukum dapat terbentuk, yaitu :

1. Karena pembentukan undang-undang (wetgeving);

2. Karena administrasi / tata usaha negara;

3. Karena peradilan (rechtsspraak);

4. karena kebiasaan / tradisi yang sudah mengikat masyarakat;

5. karena ilmu (wetenschap). ${ }^{14}$

Berdasarkan aliran Legisme ${ }^{15}$ dan Freie Rechtslehre ${ }^{16}$ tentang rechtvinding maka dapatlah disimpulkan bahwa :

a. Aliran Rechtsvinding merupakan aliran antara Legisme dan Freie Rechtslehre.

b. Berbeda dengan aliran Legisme dan Freie Rechtslehre, Rechtsvinding berpegang pada undang-undang tetapi tak seketat seperti aliran Legisme dan tidak sebebas aliran Freie Rechtslehre. Dengan kata lain, terikat tapi bebas (gebonden vrijheid) dan bebas tapi terikat (vrijegebondenheid).

c. Tugas hakim dalam Rechtsvinding adalah menyelaraskan undang-undang dengan keadaan sosial masyarakat yang nyata (sosiale werkelijheid) dan bila perlu menambah undang-undang disesuaikan dengan asas keadaan masyarakat

d. Kebebasan yang terikat dan keterikatan yang bebas dicerminkan dalam penafsiran hukum, dan pengisian kekosongan hukum dengan analogi, rechtsverfijning dan argumentum a contrario.

\footnotetext{
${ }^{13} \mathrm{Ibid}$, hlm 89-90

${ }^{14} \mathrm{Ibid}, \mathrm{hlm} 91$

${ }^{15}$ aliran Legisme hukum hanya berbentuk perundang-undangan (wetgeving), di luar undang-undang tidak ada hukum.

${ }^{16}$ Aliran Freie Rechtslehre merupakan aliran bebas yang hukumnya tidak dibuat oleh badan Legislatif, dan menyatakan bahwa hukum terdapat di luar undang-undang.
} 
e. Bagi hakim (dalam Rechtsvinding), jurisprudensi mempunyai arti yang penting di samping undang-undang, karena dalam jurispridensi terdapat makna hukum yang konkrit yang tidak terdapat dalam undang-undang. Perbedaannya dengan aliran Legisme dan Freie Rechtslehre ialah bahwa dalam Legisme jurisprudensi adalah sekunder, sedangkan bagi aliran Freie Rechtslehre adalah primer. ${ }^{17}$

Ter Haar, berpendapat bahwa sewaktu hakim menentukan hukum, dan menetapkan mana yang merupakan hukum dan mana yang tidak, harus selalu berhubungan dengan masyarakat. Hakim harus memberi keputusan sesuai dengan keadaan sosial masyarakat yang nyata. Dengan demikian dapat tercapai maksud daripada hukum : "suatu kedilan berdasarkan asas keadilan masyarakat". 18

C. Rechtsvinding Dalam Konsepsi Hukum Positif Indonesia

Sumber utama dalam sistem hukum nasional Indonesia adalah undangundang atau perundang-undangan, disusul dengan kebiasaan dan keputusan pengadilan. Di sini kedudukan dan peran pengadilan atau hakim sangat penting. Berlainan dengan pendapat kuno yang antara lain diucapkan oleh Montesque dalam bukunya "L'Esprit de Lois" yang menyatakan bahwa hakim itu hanya mulut atau corong dari badan legislatif, orang sekarang mengetahui bahwa selain menerapkan undang-undang, pengadilan atau hakim itu juga menemukan hukum atau bahkan sering membentuk hukum baru. 19

Setiap hakim mempunyai kedudukan, kewajiban dan sekaligus peran yang sengat penting dalam kerja hukum. ${ }^{20}$

Dalam pasal 5 (1) Undang-Undang 4 No. 44 Tahun 2009 tentang Kekuasaan Kehakiman yang menyatakan bahwa:

Hakim dan hakim konstitusi wajib menggali, mengikuti, dan memahami nilainilai hukum danrasa keadilan yang hidup dalam masyarakat. ${ }^{21}$

Ungkapan "menggali, mengikuti, dan memahami nilai-nilai hukum dan rasa keadilan yang hidup di masyarakat" memberi peran luar biasa bagi setiap hakim untuk menemukan dan memutuskan perkara, yang dalam kasus-kasus tertentu (terlebih lagi terhadap apa yang disebut dengan hard cases) tidak mustahil akan terjadi pemahaman kontekstual, bukan sekedar tekstual, dimungkinkan dengan tegas dan jelas melawan pasal-pasal tertentu kalau pasal itu dinilai sudah tidak sesuai dengan hukum dan rasa keadilan dan yang hidup di masyarakat. Dalam pemahaman seperti ini, peran hakim harus seorang "mujtahid". Jadi, hakim bukan sekedar memindahkan pasal-pasal dari undang-undang dalam pertimbangan hukumnya untuk menjatuhkan putusan, namun menurut ungkapan Paul Scholten "menjalankan 'rechtsvinding' (menemukan hukum)" ${ }^{22}$

\footnotetext{
${ }^{17}$ Ibid, hlm 90

${ }^{18}$ Ibid, hlm 92

${ }^{19}$ Mochtar Kusumaatmadja dan Arif Sidharta, Pengantar Ilmu Hukum (Buku I), Bandung, Alumni, 1999, hlm 97.

20 A. Qodri Azizy, Eklektisisme Hukum Nasional, Kompetisi Antara Hukum Islam Dan Hukum Umum, Yogyakarta, Gama Media, 2004, hlm 211.

${ }^{21}$ Lihat Pasal 5 ayat 1 Undang-Undang No. 44 Tahun 2009 tentang Kekuasaan Kehakiman.

${ }^{22}$ Ibid, hlm 212.
} 
Pengadilan dilarang menolak untuk memeriksa, mengadili, dan memutus suatu perkara yangdiajukan dengan dalih bahwa hukum tidak ada atau kurang jelas, melainkan wajib untukmemeriksa dan mengadilinya. ${ }^{23}$

Dari ketentuan Pasal 10 Undang-Undang No. 44 Tahun 2009 tentang Kekuasaan Kehakiman di atas tampak jelas bahwa pengadilan atau hakim dalam sistem hukum Indonesia bukanlah hakim yang pasif yang merupakan corong belaka dari badan perundang-undangan seperti digambarkan oleh Montesque, namun aktif berperan di dalam menemukan atau membentuk hukum baru. Jelas bahwa pengadilan atau hakim mempunyai kedudukan penting dalam sistem hukum Indonesia, karena ia melakukan fungsi yang pada hakekatnya melengkapi ketentuan-ketentuan hukum tertulis melalui pembentukan hukum (rechtsvorming) dan penemuan hukum (rechtsvinding). Dengan perkataan lain, pengadilan atau hakim dalam sistem hukum Indonesia yang pada dasarnya tertulis itu mempunyai fungsi membuat hukum baru (creation of new law). Karena itu sistem hukum Indonesia, walaupun merupakan sistem hukum tertulis dan tidak tertulis, namun merupakan sistem terbuka. Dengan demikian dapat dikatakan bahwa pengadilan atau hakim itu merupakan unsur yang cukup penting, tidak saja di dalam menemukan hukum tetapi juga di dalam mengembangkan hukum. ${ }^{24}$

Berdasarkan pasal 10 Undang-undang No. 44 Tahun 2009 tentang Kekuasaan Kehakiman diatas maka hakim dilarang menolak perkara meskipun perkara tersebut berat atau ringan, lama atau baru sama sekali. Apabila ada perkara, hakim melakukan tindakan-tindakan sebagai berikut :

1. Ia menempatkan perkara dalam proporsi yang sebenarnya.

2. Kemudian ia melihat pada undang-undang.

- Apabila undang-undang menyebutkannya, maka perkara diadili menurut undang-undang.

a. Apabila undang-undangnya kurang jelas, hakim mengadakan penafsiran.

b. Apabila ada ruangan-ruangan kosong, hakim mengadakan kontsruksi hukum, rechtsverfijning atau argumen a contrario.

3. Di samping itu, hakim juga melihat jurisprudensi dan dalil-dalil hukum agama, adat dan sebagainya yang berlaku di dalam masyarakat. ${ }^{25}$

Setiap penemuan hukum yang dilakukan oleh hakim tentu mempunyai tujuantujuan yang ingin dicapai. Adapun tujuan-tujuan dilakukannya Rechtsvinding, diantaranya adalah :

1. Sebagai sosial kontrol;

2. Sebagai perubahan masyarakat;

3. Sebagai penciptaan hukum;

4. Sebagai alat pengisian kekosongan hukum;

5. Sebagai penerapan hukum;

6. Sebagai pelaksanaan hukum.

\section{METODE PENELITIAN}

\section{A.Jenis Penelitian}

Penelitian ini menggunakan metode yang diharapkan dapat lebih meningkatkan bobot objektifitas dari penelitian ini. Adapun yang penulis

\footnotetext{
${ }^{23}$ Lihat Pasal 10 Undang-Undang No. 44 tahun 2009 tentang Kekuasaan Kehakiman

${ }^{24}$ Mochtar Kusumaatmadja dan Arif Sidharta, Loc. cit, hlm 99.

${ }^{25}$ R.Soeroso, Op. cit, hlm 93.
} 
gunakan adalah Doktrinal legal research ${ }^{26}$, yang dimaksud doctrinal legal research adalah segala upaya yang dilakukan oleh peneliti untuk memperoleh dan menghimpun segala informasi tertulis yang relevan dengan masalah yang diteliti. Informasi ini dapat diperoleh dari buku-buku, laporan penelitian, karangan ilmiah, tesis atau disertasi, ensiklopedia, peraturan-peraturan, dan sumber-sumber lain.

B. Sumber Data

Untuk memperoleh data-data yang diperlukan sesuai tema penelitian, maka penelitian ini menggunakan sumber data dari:

1) Sumber data primer, yaitu : Undang-Undang No. 44 tahun 2009 tentang Kekuasaan Kehakiman dan perundang-undangan lainnya yang berkaitan dengan tema penelitian.

2) Sumber data sekunder, yaitu : buku-buku litelatur, jurnal, karya ilmiah yang berkaitan dengan tema penelitian.

3) Sumber data tersier, yaitu : keterangan-keterangan yang berkaitan dengan sumber data primer dan sekunder, baik di surat kabar maupun di media elektronik semisal berita dan informasi dari internet.

C.Teknik Pengumpulan data

Studi kepustakaan merupakan metode tunggal yang dibutuhkan dalam penelitian hukum normatif. Yang disebut juga sebagai penelitian kepustakaan atau atau studi dokumen, karena penelitian ini dilakukan atau ditujukan hanya pada peraturan-peraturan yang tertulis atau bahan-bahan hukum lain. Penelitian kepustakaan atau studi dokumen disebabkan penelitian ini lebih banyak dilakukan terhadap data yang bersifat sekunder yang ada di perpustakaan. Termasuk dalam data sekunder meliputi bukubuku, buku-buku harian, surat-surat pribadi dan dokumen-dokumen dari pemerintah. ${ }^{27}$ Untuk mengumpulkan data yang dibutuhkan, penulis menggunakan tehnik yakni Dokumentasi. Metode ini berguna untuk mencari data mengenai hal-hal yang variabel yang berupa catatan, bukubuku, surat kabar, majalah dan penelusuran media internet.

D. Tehnik Analisis

Data-data yang terkumpul di analisa berdasarkan isi (analisi content)dan analisa deskripsi (deskriptif analis). Untuk data-data yang bersumber dari buku, jurnal, majalah, dan sejenisnya peneliti kumpulkan dan dianalisa sesuai dengan yang dimaksud tema penelitian.

\section{HASIL DAN PEMBAHASAN}

A. Konsep Rechtsvinding Dalam Lingkup Hukum Perdata Indonesia

Menurut Sudikno Mertokusumo,28 dalam mengadili perkara, hakim melakukan tiga tindakan secara bertahap :

1. Mengkonstantir perkara, artinya melihat, mengakui atau membenarkan telah terjadi peristiwa yang diajukan. Cara hakim mengkonstantir perkara ialah dengan memeriksa gugatan, jawaban, replik dan duplik, dan juga alatalat bukti seperti yang disebutkan dalam pasal 164 HIR.

\footnotetext{
${ }^{26}$ Suhadi Ibnu dkk., Dasar-Dasar Metodologi Penelitian, Malang, Penerbit Universitas Negeri Malang dan Lembaga Penelitian Universitas Negeri Malang, 2003, hlm. 23.

${ }^{27}$ Bambang waluyo, Penelitian Hukum Dalam Praktek, ( Jakarta: Sinar Grafika, 2002)

${ }^{28}$ Sudikno Mertokusumo, Hukum Acara Perdata Indonesia, Liberty, Yogyakarta, 1998, hlm 110-111
} 
2. Mengkualifisir perkara, artinya menilai peristiwa yang telah dianggap benarbenar terjadi itu termasuk hubungan hukum apa atau yang mana. Di sini hakim harus menemukan hukum yang akan diterapkan pada peristiwa yang telah dikonstantir tadi. Bila hukumnya telah jelas dan tegas maka tugas hakim adalah menerapkan peraturan hukum yang ada terhadap peristiwa tersebut. Tetapi kalau peraturan hukumnya tidak tegas dan tidak jelas, maka dalam hal ini hakim harus melakukan penafsiran terhadap peraturan hukum yang ada. Bila dijumpai kekosongan hukum, maka hakim harus mengkronstruksi hukum atau bahkan menciptakan hukum bila memang tidak ada hukumnya sama sekali. Namun demikian, kebolehan hakim dalam menciptakan hukum haruslah tidak bertentangan dengan seluruh sistem perundang-undangan yang ada serta bertujuan untuk memenuhi rasa keadilan masyarakat dan tuntutan kemajuan zaman.

3. Mengkonstituir perkara, artinya hakim menetapkan hukumnya terhadap peristiwa tersebut dan sekaligus memberi keadilan bagi para pihak yang berperkara. Di sini hakim berlaku sebagai pembentuk hukum (judge made law) karena dalam mengadili perkara, hakim telah menentukan hukumnya secara konkrit (in concreto). Jadi bila pembentuk undang-undang (pemerintah dan DPR) membentuk hukum yang sifatnya obyetif abstrak (undang-undang), karena sifatnya umum dan berlaku untuk seluruh masyarakat, maka di sini hakim sebagai pembentuk hukum yang sifatnya konkrit, artinya berlaku khusus terhadap pihak yang berperkara saja.

Macam-macam metode penafsiran menurut R. Soeroso adalah :29 Berikut ini adalah penjelasan dari masing-masing penafsiran tersebut :

1. Penafsiran Gramatikal, atau taalkunding adalah penafsiran menurut tata bahasa atau arti perkataan (istilah). Dalam hal ini hakim wajib mencari kata-kata yang dimaksud yang lazim dipakai dalam percakapan sehari-hari, dan hakim dapat menggunakan kamus bahasa atau maminta penjelasan dari ahli bahasa.

Contoh : pasal 1464 KUH Perdata yang menyebutkan "jika pembelian dibuat dengan memberi uang panjar, tidak dapatlah salah satu pihak membatalkan pembelian itu dengan menyuruh memiliki atau mengembalikan uang panjar tersebut". Jelas bahwa hakim tidak perlu memberikan penafsiran lain dari arti pasal tersebut karena telah jelas seperti apa yang disebutkan oleh teksnya.

2. Penafsiran Historis atau Sejarah, penafsiran yang dilakukan hakim dengan cara meneliti sejarah daripada undang-undang yang bersangkutan, karena pada dasarnya setiap ketentuan perundang-undangan mempunyai sejarah dan dari sejarah perundang-undangan tersebut hakim dapat mengetahui maksud dari pembuatnya. Para ahli berpendapat bahwa penafsiran historis atau sejarah ini ada dua macam: satu, Penafsiran menurut sejarah hukumnya artinya, untuk mendapatkan pemahaman yang jelas atas suatu pasal undang-undang, hakim melakukan telaah sejarah yang melatar belakangi terbentuknya undang-undang atau pasal tersebut. Dalam hal ini, yang dipelajari hakim adalah asas-asas yang berlaku, aliran atau madzhab yang mempengaruhinya, dan sebagainya. Contoh : Undang-undang No. 1 Tahun 1974 hanya dapat dipahami dengan meneliti sejarah tentang

${ }^{29} \mathrm{Ibid}, \mathrm{hlm} 99$. 
emansipasi wanita. Dua, Penafsiran menurut sejarah penetapannyaartinya, hakim melakukan studi historis terhadap latar belakang penetapan suatu undang-undang atau pasal tersebut. Dalam hal ini, hakim dapat mempelajari catatan/berita acara kesepakatan pembentuk undang-undang tersebut, memo, surat-surat serta dokumen penting lainnya.

3. Penafsiran Sistematis, suatu penafsiran yang menghubungkan pasal yang satu dengan pasal yang lain dalam suatu perundang-undangan yang bersangkutan atau pada perundang-undangan hukum lainnya, atau membaca penjelasan suatu perundang-undangan. Contoh : pasal $1330 \mathrm{KUH}$ Perdata mengemukakan bahwasanya tidak cakap untuk membuat perjanjian antara lain orang-orang yang belum dewasa. Bunyi lengkapnya pasal 1330 KUH Perdata ialah :

"Tidak cakap membuat perjanjian adalah :

a. Orang yang belum dewasa

b. Orang yang di taruh di bawah Pengampuan

c. Orang perempuan dalam hal yang ditetapkan oleh undang-undang dan pada umumnya orang kepada siapa undang-undang telah melarang membuat persetujuan tertentu".30

B. Kendala-kendala Yang Di Hadapi Dalam Rechtsvinding

Untuk mengetahui kendala-kendala rechtsvinding yang dihadapi dalam lingkup hukum perdata Indonesia, maka berikut ini adalah kendala-kendala yang dihadapi.

Asas "hakim pada peradilan yang lebih rendah terikat untuk mengikuti putusan yang dijatuhkan hakim peradilan yang lebih tinggi".

Menurut M. Yahya Harahap ${ }^{31}$, kewajiban kepada para hakim untuk mesti terikat mengikuti putusan terdahulu secara totalitas, telah menempatkan para hakim untuk menerima dan mengikuti yurisprudensi secara "irrasional", sehingga memadamkan nalar dan perasaan mereka untuk menilai apakah putusan yang diikuti itu secara potensial menegakkan kebenaran-keadilan atau tidak. Keadaan seperti itu, sekaligus pula mematikan dan "memandulkan" profesionalisme dan kebebasan kreatifitas para hakim.

Berikut ini adalah beberapa hal mengenai konsep rechtsvinding dalam hukum perdata Indonesia.

Pertama, dalam konsep pengertian, ada beberapa unsur "penemuan hukum". Seperti yang telah disebutkan sebelumnya bahwa penemuan hukum adalah proses pembentukan hukum oleh hakim, atau aparat hukum lainnya yang ditugaskan untuk penerapan peraturan hukum umum pada peristiwa hukum konkrit. Dari pengertian tersebut dapat diketahui, bahwa unsur penemuan hukum di sini adalah antara lain :

a. Adanya proses;

b. Pembentukan hukum;

c. Oleh hakim atau aparat hukum,;

d. Pada peristiwa konkrit.

Kedua, adanya sebuah rechtsvinding dalam sistem hukum perdata Indonesia tersebut tidak dapat dilepaskan pula dari sumber hukum yang menjadi landasannya. Jika dalam hukum perdata Indonesia mendasarkan

\footnotetext{
${ }^{30}$ Lihat Pasal 1330 KUH Perdata

${ }^{31}$ M. Yahya Harahap, Beberapa Tinjauan Tentang Permasalahan Hukum, Buku kesatu, Citra Aditya Bakti, Bandung, 1997, hlm 197-211.
} 
sumber hukumnya pada peraturan perundang-undangan, kebiasaan, yurisprudensi, traktat, dan doktrin.

Penggunaan sumber hukum. rechtsvinding, didalam konteks hukum positif Indonesia, undang-undang didahulukan dari sumber-sumber hukum lainnya. Di dalam hal ini, jika hendak mencari hukum suatu peristiwa, maka dicarilah terlebih dahulu dalam undang-undang, karena undang-undang bersifat otentik dan tertulis, yang lebih menjamin kepastian hukum. Jika hal peristiwa tersebut dinilai tidak ada dalam undang-undang, maka dilihat di dalam yurisprudensi, dan seterusnya.

Ketiga, dalam menyimpulkan sebuah hukum, maka tidak bisa lepas dari aliran-aliran yang mempengaruhinya. Jika dalam hukum perdata Indonesia terdapat aliran Legisme, aliran Hukum Bebas, dan aliran Rechtsvinding (penemuan hukum).

Keempat, dalam melakukan rechtsvinding, hukum perdata Indonesia inipun sama-sama memiliki konsep metode rechtsvinding yang dipergunakan. Untuk mengetahui metode rechtsvinding dalam hukum perdata Indonesia maka dapat dilihat dari tabel perbandingan berikut :

1. Analogi, dalam hal ini adalah memberi ibarat (kias) atau memperluas arti pada kata-kata atas suatu ketentuan undang-undang sesuai dengan asas hukumnya, sehingga suatau peristiwa yang sebenarnya tidak dapat dimasukkan, lalu dianggap sesuai dengan peraturan tersebut.

2. Penghalusan Hukum, pada dasarnya dalam menyelesaikan suatu perkara hakim tidak dapat menerapkan suatu ketentuan meskipun ketentuan itu menyebutkan secara jelas, karena jika ketentuan itu dilaksanakan justru akan menghasilkan putusan yang tidak adil atau tidak sesuai dengan realitas sosial yang ada. Dalam hal ini hakim membuat suatu metode sendiri yang sesuai dengan realitas sosial yang dihadapinya.

3. Penafsiran Teleologis atau Sosiologis, penafsiran ini pada dasarnya menyesuaikan dengan melihat keadaan sosial yang ada dalam masyarakat sekarang. Fungsinya adalah untuk mencari tujuan sosial baru dari peraturan tersebut, jika sudah dianggap tidak sesuai lagi dengan tujuan sosial yang ingin dicapai.

\section{KESIMPULAN DAN SARAN}

A. Kesimpulan

Berdasarkan apa yang telah dijelaskan pada bab-bab sebelumnya, maka dapat disimpulkan :

1. Konsep rechtsvinding menurut hukum perdata Indonesia memiliki pengertian, istilah rechtsvinding yang di dalam hukum positif Indonesia berarti "penemuan hukum" dapat terjadi jika terdapat peristiwa dan tidak ditemukan aturan secara tertulis dalam suatu perundang-undangan maka diberikan kewenangan kepada hakim dalam memberikan penafsiran untuk menemukan hukum yang akan diterapkan.

2. Analisis rechtsvinding dalam hukum perdata Indonesia tidak bisa dilepaskan dari metode-metode yang dipakainya, karena metode-metode tersebut adalah alat untuk membaca undang-undang. Dari perbandingan metode rechtsvinding yang telah dikemukakan, maka : analisis dapat dilakukan dengan cara Analogi hukum, Penghalusan Hukum dalam penghalusan hukum, seorang hakim boleh menyimpang dari undang- 
undang dan membuat metode atau keputusan sendiri, Penafsiran Teleologis atau Sosiologis, Penafsiran Sejarah atau Historis, dan Penafsian Otentik

B. Saran

1. Pertama, sudah selayaknya untuk tidak membatasi para hakim untuk selalu tunduk terhadap asas Binding force of precedent, yaitu asas bahwa hakim terikat pada putusan-putusan sejenis terdahulu. Karena hal ini dapat "memandulkan" dan mematikan kreatifitas hakim dalam menemukan hukum.

2. Kedua, hakim harus berani melakukan penafsiran kembali terhadap undang-undang sehingga sesuai dengan tuntutan masyarakat dan zaman.

\section{REFERENSI}

\section{A. Buku}

Ardhiwisastra, Yudha Bhakti, Penafsiran Dan Konstruksi Hukum, Bandung, Alumni, 2000.

Azizy, A Qodri, Eklektisisme Hukum Nasional, Kompetisi Antara Hukum Islam Dan Hukum Umum, Yogyakarta, Gama Media, 2004,

Hosen, Ibrahim, Memecahkan Permasalahan Hukum Baru, (Ijtihad Dalam Sorotan), Mizan, Bandung, 1996,

Kansil, C.S.T., Pengantar Ilmu Hukum dan Pengantar Tata Hukum Indonesia, Jakarta, Balai Pustaka, 1995

Kusumaatmadja, Mochtar dan Sidharta, Arif, Pengantar Ilmu Hukum (Buku I), Bandung, Alumni, 1999

Mertokusumo, Sudikno, Bab-Bab Tentang Penemuan Hukum, Yogyakarta, Liberty, 2000, 1998.

, Hukum Acara Perdata Indonesia, Liberty, Yogyakarta, , Penemuan Hukum, Yogyakarta : Liberty, 2001.

Rahardjo, Satjipto, Hukum Dan Masyarakat, Bandung: Angkasa, 1986.

Raharjoekoesoemah, Datje, Kamus Bahasa Belanda-Indonesia, Jakarta, Rineka Cipta, 1991.

Sudarsono, Pengantar Ilmu Hukum, Jakarta, Rineka Cipta, 2001

Suhadi, Ibnu dkk., Dasar-Dasar Metodologi Penelitian, edisi revisi, Malang: Penerbit Universitas Negeri Malang dan Lembaga Penelitian Universitas Negeri Malang, 2003.

Tri Ratna, Rini, Recthsvinding Dalam Konsepsi Hukum Perdata Dan Hukum Pidana, Skripsi, UMM, 2000.

Usman, Rachmadi, Perkembangan Hukum Perdata, dalam Dimensi Sejarah Dan Politik Hukum Di Indonesia, Jakarta: Pustaka Sinar Harapan, 2003.

Utrecht, E. dan Shaleh Djindang, Moh., Pengantar Dalam Hukum Indonesia, Jakarta, Ikhtiar Baru, 1983.

Wasis, Pengantar Ilmu Hukum, Malang: UMM Press, 2002.

Yahya Harahap, M., Beberapa Tinjauan Tentang Permasalahan Hukum, Buku kesatu, Citra Aditya Bakti, Bandung, 1997.

B. Kitab Undang-undang

Kitab Undang-undang Hukum Perdata (Burgerlijk Wetboek).

UU No. 44 Tahun 2009 Tentang Kekuasaan Kehakiman. 
Undang-undang No. 2 Tahun 1986 Tentang Peradilan Negeri.

Undang-undang No. 7 Tahun 1989 Tentang Peradilan Agama.

Undang-undang No. 5 Tahun 2004 Tentang Mahkamah Agung. 